\title{
The Emergence of Academies in the Eastern Townships of Lower Canada and the Invisibility of the Canada-U.S. Border
}

\section{Anthony Di Mascio}

Bishop's University

\section{ABSTRACT}

By examining the emergence of academies along the borderland of the United States and the Eastern Townships of Lower Canada in the nineteenth century, this study highlights American influences and innovations that contributed to the development of schooling in the region. When American settlers arrived in the wake of the American Revolution, they began to reestablish the familiar social and cultural institutions that they had left behind in the Thirteen Colonies. Among those institutions were academies based on the New England model. Academies in the Eastern Townships emulated the culture of New England academies in four major ways: organizational structure; curriculum; the use of American books; and, reliance on American teachers. This study argues that by examining American influences on education, we may better situate the history of Quebec education in its continental context, and may better understand the trends that have shaped the common experience of schooling on both sides of the border.

\section{RÉSUMÉ}

L'étude de l'émergence des "académies " au début du XIX ${ }^{\mathrm{e}}$ siècle dans la région frontalière entre les États-Unis et les Cantons de l'Est du Bas-Canada met en lumière les influences et les innovations américaines qui contribuèrent au développement de l'éducation dans cette région. Lorsque les colons américains arrivèrent dans la foulée de la révolution américaine, ils commencèrent par établir des institutions culturelles et sociales comme celles laissées derrière dans les Treize colonies. Parmi celles-ci, on retrouve les académies calquées sur le modèle de la Nouvelle-Angleterre. Dans les Cantons de l'Est, ces institutions ont adopté quatre caractéristiques principales des académies américaines : la structure organisationnelle, le programme scolaire, l'emploi des mêmes livres et le recrutement d'enseignants américains. L'auteur soutient qu'en examinant les influences américaines en éducation, nous pourrions découvrir le contexte continental de l'histoire de l'éducation bas-canadienne et comprendre davantage les tendances qui ont façonné l'expérience commune de l'éducation des deux côtés de la frontière. 
While the forty-ninth parallel is often proclaimed as the longest undefended border in the world, we know very little about its historical making and less about its historical meaning. Questions of shared identity along borderlands have attracted increased scholarly attention in recent decades. Led by a diverse range of scholars in a variety of disciplines, the literature on borderlands has begun to reconsider the meaning of divergences and intersections of communities and peoples characteristically examined in isolation due to the presence of borders. ${ }^{1}$ In North America, the focus has tended to be on the Mexico-U.S. border. ${ }^{2}$ Although the meaning of the Canada-U.S. border has captivated Canadian, and to a lesser extent American, scholars, when it is considered concentration is usually placed heavily on politics and the economy, with the border representing a continually negotiated line in relation to cultural identity, social values, and economic interdependence. ${ }^{3}$ What we know less about, however, are the patterns of cultural similarities and the intersections of communities along the Canada-U.S. border that borderland scholars of the Mexico-U.S. border have shed much light on. In other words, the discourse surrounding the Mexico-U.S. borderland as a complex intersection of socio-cultural integration has no real equivalent in Canada. Analyses of the lived experience of Canadians and Americans along the border, however, can offer new ways to discuss and understand the cultural manifestations and meanings of the Canada-U.S. border. In educational history, such analyses can help us better appreciate the trends that shaped the common experience of the rise of mass schooling in both nations. Though scholars are aware of this shared history, there has been surprisingly little scholarship on the subject. ${ }^{4}$

A borderland study of education in Quebec can offer a unique regional perspective of educational developments in a province characterized by its geographic and demographic diversity. Most historians acknowledge that there were pronounced differences in how schooling developed and was experienced throughout the province. The earliest generations of educational historians tended to conclude that the expansion of schooling in nineteenth-century Quebec was sluggish at best, and, with an emphasis on Francophone communities, rural Quebec in particular was characterized as an educational backwater devoid of interest in education. ${ }^{5}$ Revisionist scholars delved deeper into the motives and actions behind school reform in the nineteenth century, but continued to find an imbalance in educational developments, lamenting an indifference to education, especially pronounced in Francophone rural regions. ${ }^{6}$ Since the 1980s, the writing of educational history in both French and Englishspeaking Canada has reassessed school reform in nineteenth-century Quebec, and has paid particular attention to local developments, which highlight further the range of experiences in the province's educational history. ${ }^{7}$ In the most recent work on education in Lower Canada, Bruce Curtis demonstrates that the movement for schooling was anything but sluggish in the early nineteenth century, and brings to light a massive political undertaking in education, including enormous government spending on schooling often representing more than one-fifth of the state budget. Still, Curtis also concludes that while government attempted to promote the expansion of schooling through lavish expenditures on education, there was little appetite for schooling in the countryside where "rural ignorance" remained widespread. ${ }^{8}$ 
The Anglo-American borderland community of the Eastern Townships in the nineteenth century, however, complicates the idea of rural indifference to school reform. Examining local reports and petitions sent to provincial officials from the Eastern Townships, J.I. Little has demonstrated a considerable appetite among Anglophones for school reform in that region, which, although marked by resistance to government plans to enact an elaborate system of schooling, nevertheless led to a pronounced proliferation of locally controlled schools by mid-century. ${ }^{9}$ Focusing on Quebec Protestant superior and secondary education, particularly in the Eastern Townships, Anne Drummond suggests that educational leaders in this community created many of the preconditions for late nineteenth and early twentieth century provincial public schooling. ${ }^{10}$ Thus, while some scholars have found little impulse for school reform in the countryside, it is important to note that the scope of that countryside is almost entirely that of Francophone Quebec where resistance and indifference to schooling was most pronounced. The popularity of schooling in the Anglophone countryside of the Eastern Townships suggests a different experience in education. What, then, may have influenced that experience?

What follows is an effort to address this question by examining the emergence of academies along the borderland region of the Eastern Townships in nineteenthcentury Lower Canada. Such an examination can broaden our understanding about the development of schooling in Quebec, and about the ways in which education was experienced differently throughout the province. Educational ideas and innovations in the Eastern Townships often reflected what was happening in schools south of the border in the United States rather than what was happening elsewhere in the province. Such influences may have contributed significantly to the rise of schooling in the nineteenth century in ways that we have not yet considered. In a borderland region such as the Eastern Townships, the close proximity of a developing educational culture in the early American republic, particularly in New England, and the influences of that culture north of the border, may shed additional light on the educational history of Quebec and beyond.

In the eighteenth and nineteenth centuries, when American settlers started establishing communities along the Lower Canada-U.S. border in what would become known as the Eastern Townships, they also began to establish the familiar social and cultural institutions that they had left behind with their kith and kin in the Thirteen Colonies. Among those institutions were academies. American teachers and schoolmasters, who easily traversed an unprotected and permeable border, established a number of academies in the Eastern Townships. These academies, which were based on the New England model, contributed significantly to the development of schooling in the region. Academies in the Eastern Townships emulated the culture of academies in New England in four major ways: organizational structure; curriculum; the use of American books, and, finally, reliance on American teachers.

This study is influenced by Kerry Alcorn's recent work on U.S. culture and education in the formation of schooling in Saskatchewan. ${ }^{11}$ In many ways, the development of schooling along the Quebec-U.S. border in the nineteenth century more closely resembles developments along the Prairie-U.S. border in the early twentieth century 
than it does developments in neighbouring jurisdictions during its own time. For instance, the Eastern Townships of the early nineteenth century was predominantly rural and agrarian. The rural demographic makeup tended to emphasize practical and useful education more indicative of a Jeffersonian Democracy that, as Alcorn points out, dominated the Prairie outlook and favoured life on the land. ${ }^{12}$ Rural New England, and especially Northern Vermont in these years, were similarly influenced by Jeffersonian Democracy and the prominence of agrarian life. ${ }^{13}$ These ideas traveled northward into the Eastern Townships, and, as will be discussed, influenced the community's outlook on school development.

English Canadian historians of education have tended to neglect the ways in which such ideas traveled northward. In part, this may be attributed to a historiography in English Canada, particularly Ontario, which emphasizes anti-Americanism as an impetus for school development. That historiography is often assumed to apply to other parts of Canada. The shared patterns of educational developments and exchange of educational ideas that we find along the Prairie-U.S. border in the early twentieth century and the Quebec-U.S. border in the nineteenth century, however, challenge us to reconsider such presumptions. Like Alcorn, however, my intention in the present study is not to replace or refute the established history of education in Quebec, but rather to offer an alternative way to conceptualize schooling's origins in the province. The Eastern Townships offer us a unique opportunity to explore American influences by virtue of its demographic and geographic history. For nearly 100 years its social and cultural development was shaped by its demography — namely, Anglo-American settlers - and its shared geography with the New England states, particularly that of northern, rural Vermont.

\section{The Structural Influences of the New England Academy}

Academies in New England began to appear in the late eighteenth century and multiplied rapidly in the 1820 s. They can trace their philosophical origins to John Milton's educational plans for Puritan higher education in seventeenth-century England in the wake of restrictive legislation in 1662 that eliminated Puritan teaching from Oxford and Cambridge Universities. ${ }^{14}$ Milton argued for a more practical curriculum, but as with most schools in England at the time, his plan for the academies remained heavily influenced by the classics. Agriculture in Milton's model, for example, was to be learned from Cato and Varro; law from Moses and Lycurgus; and so on. ${ }^{15}$ The New England academies of late eighteenth and early nineteenth century America, however, took on a much more practical bent. Schooling in the U.S. generally tended to reject things British and favour populism. The New England academies were designed to provide schooling to rural families who wanted their children to have an education beyond that of the local primary school, yet one that was more elementary and practical than a college. ${ }^{16}$

A more popular model of education appealed to the American settlers of the Eastern Townships, who generally rejected district and grammar schools in favour of academies. ${ }^{17}$ For example, when the colonial government attempted to create a 
centralized system of education at the turn of the nineteenth century via the Royal Institute schools, the plan was largely rebuffed in the Eastern Townships. These Royal Institute schools were an early attempt by the colonial government to introduce a system of public education in Lower Canada. In 1801, the Assembly of Lower Canada passed "An Act for the Establishment of Free Schools and the Advancement of Learning in the Province." The idea behind the act was to provide free tuition for poor children and nominal fees for others. One or more free school was to be established in each township or parish throughout the province offering a basic curriculum aimed at providing "the first Rudiments of useful Learning." 18 The design of the system was highly centralized, with the governor at the helm who alone could appoint members to the Board of Trustees to administer the schools. Ultimately, though, as historian Roger Magnuson has noted, the success of the Royal Institute schools hinged on the initiative and cooperation of the local population because neither the governor nor the Board of Trustees could open a school or force a given population to do so. ${ }^{19}$ If popular support was necessary, then the proponents of the Act might have actually sabotaged its future by stacking the governing board with High Church Anglicans, presided over by the Anglican Bishop of Quebec. As Bruce Curtis points out, from its onset the proposed school system "was attacked more or less ferociously from all quarters." ${ }^{20}$ In the Eastern Townships of Lower Canada, the Royal Institute plan failed almost immediately. Of the three successful Royal Institute schools established in the Eastern Townships at Danville, Cookshire, and Eaton, two, those at Danville and Cookshire, broke their association with the Royal Institution almost immediately, and eventually converted themselves to popularlyrun academies. $^{21}$

A French-Canadian and Catholic population wary of Anglican-controlled schools might help explain why the Royal Institute schools were unpopular in most of Lower Canada, but the Eastern Townships of the first half of the nineteenth century was neither. Its demographic makeup was mainly Anglo-American and Protestant. Why, then, did the Royal Institute schools also fail in the Eastern Townships? Understanding the answer to this question requires us to consider the differences among EnglishCanadians throughout British North America. This, in turn, requires us to consider the influence of the Eastern Townships' shared geography with the New England states in the region's social and cultural development, including the emulation of its educational culture. Anne Drummond points out that in the early years, voluntary, or privately financed, elementary schools in the Eastern Townships flourished where the Royal Institute schools failed. Communities in the Eastern Townships, in Drummond's assessment, interpreted the Royal Institute schools as an attempt by the Anglican minority to proselytize among the other Protestant denominations, just as much as they did among Catholics, in order to assure the ascendancy of the Church of England. ${ }^{22}$ Henry Leslie Rennie draws a similar conclusion, contending that the "reasons for the failure are quite apparent. The Institution was represented by fourteen Protestants and four Roman Catholics; the Anglican Bishop was its President, and most of the teachers were from England." ${ }^{23}$ J.I. Little is more nuanced in his interpretation, and while he considers the role of the Royal Institute schools in the 
Eastern Townships as "significant," he also concludes that "religious dissenters resented Anglican attempts to control education." 24

In an area that was clearly craving schools, and among a population of parents establishing a number of schools and academies, one might expect the lure of government grants and government-supported schools to have had appeal. Anglo-American and heterogeneously Protestant settlers, however, like their French-Canadian and Catholic neighbours in other parts of the province, rejected the rigid control of a Church of England elite. In other words, the Royal Institute schools might have had trouble taking hold in the Eastern Townships precisely because of their British links and association with a more classical curriculum not suited to the needs of the AngloAmerican inhabitants of the region. Instead, beginning in the late 1820 s we see, as in New England a few years earlier, the emergence and then the rapid multiplication of the more populist academies throughout the Eastern Townships.

Part of the appeal of academies might well have been their commitment to populism and local control, which reflected the ideas of a population itself influenced by American ideas of populism. Academies in the Eastern Townships, such as Charleston Academy (the region's first, established in 1829 in what is now Hatley, Quebec), were usually administered by a board of trustees or managers under the stewardship of local shareholders or proprietors who owned them. They were not intended to make a profit, but rather to break even. They were self-sustaining schools, but most received a subsidized government grant sponsored by their local Member of the Legislative Assembly (these became harder to attain as the years went on). As in New England, the academy buildings were much larger in scale than district schoolhouses, and were intended for community uses other than schooling. They were often two stories high, and, in addition to classrooms, some academies had an upper floor where students could board, and where teachers, either itinerant or recruited from the United States, would themselves, as in the New England tradition, also take board. ${ }^{25}$ Jean-Baptiste Meilleur, Superintendent of Education in Lower Canada, in his 1846-47 Report of the Superintendent of Education For Lower Canada, lauded the practice of boarding the teacher in the Eastern Townships academies, which he pointed out was also a custom in the United States, and suggested that other regions in the province should take note of the successful influence such a practice was having on the educational development of the Eastern Townships. ${ }^{26}$ Local ownership, local governance, and the communal structure of teaching and learning gave the academies a type and quality of populism that distinguished it from other schools in the province.

Such characteristics, however, did not distinguish the academies from their counterparts in New England, and various boards of trustees and local school advocates often found the academies of the Eastern Townships in competition with New England academies in the recruitment and retention of students. The 1848 catalogue of Stanstead Seminary and its low student numbers quickly became a subject of noteworthy concern in the Stanstead Journal. ${ }^{27}$ "We have frequently heard it remarked as singular," the newspaper read, "that this institution, with its local advantages and liberal allowance from Government, should remain so dormant and lifeless, while similar schools in Vermont were flourishing, and drawing no inconsiderable portion 
of their revenue from the Eastern Townships." Why, the newspaper asked rhetorically, was the pull toward New England so successful? "But a moment's reflection will show that there is no mystery in the matter. Those acquainted with the management of the academies — say in Orleans County [Vermont] — know that no endeavours are spared by Trustees, Teachers, and friends of the school to induce pupils to attend. The schools are widely advertised through newspapers, catalogues, etc. Need we say that the reverse has been the case with the Stanstead School?"28

The Stanstead Journal went on to commend the administration of its new American headmaster, Mr. J.A. Jameson, under whose leadership Stanstead Seminary was gradually increasing its numbers. He did so by borrowing the administrative practices of the New England academies, and specifically by widely advertising the academy in newspapers, both throughout the province and across the border. He also introduced a number of new innovations from New England, such as the establishment of a Teachers' Institute that focused on teacher preparation and the recruitment and hiring of specialist teachers for music, French, anatomy, and physiology. After his four years at the seminary, he had increased its popularity and raised its attendance numbers from 86 in 1848 to 234 in 1852, attracting pupils from not only the Eastern Townships, but Vermont and New Hampshire as well. ${ }^{29}$

\section{American Curricular Influences}

The curriculum also distinguished the academies from other schools in Quebec. Like their New England counterparts, the curriculum of the Eastern Townships' academies was heavily influenced by American values of practical education. The sixty-two boys and fifty-one girls who attended Charleston Academy in 1847 were reported to have taken the following subjects: English, Geography, Arithmetic, Algebra, Geometry, Surveying, Natural Philosophy, Chemistry, Logic, Rhetoric, French, Latin, and, finally, Greek. ${ }^{30}$ The classical curriculum of English Academies clearly did not form the bulk of Charleston Academy's course offerings. The Report of the Superintendent of Education for Lower Canada for 1857 printed the 1856 course offerings for Charleston Academy. Despite the inclusion of Latin and Greek in the curriculum, of the 26 subjects that were taught by four teachers that year, the practical dominated, with new practical course offerings such as Bookkeeping, Commercial Studies, Embroidery, and Mental Calculation. ${ }^{31}$ The increased course offerings, entirely in practical subjects, must have reflected both the popularity and the appetite for such courses among the parents of those attending.

This seems to have been the case at Stanbridge Academy as well, an academy in Missisquoi County roughly fifty kilometers north of the Vermont border, where the practical course offerings dominated the curriculum as published in the Prospectus of the academy in 1860. In fact, Stanbridge Academy explicitly advertised its shift away from a classical curriculum, noting that "Lectures are occasionally given by the Principal, upon subjects more immediately connected with the practical studies of the students to awaken their minds to new thought, renew activity, and increase a love of study." As with other academies in the Eastern Townships at the time, 
Stanbridge was marked by a populist philosophy more indicative of the New England tradition in which "It is the aim of the teacher to induce the pupil to study, and to create habits of correct and independent thought. They do not propose to teach everything, but to teach the scholar well, what they undertake." 32 J.I Little also finds the predominance of a practical curriculum in his research on Richmond Academy in 1841, where "the very full curriculum consisted of writing, arithmetic, English grammar, geography, book-keeping, 'meseration,' gauging, the elements of land surveying, geometry, trigonometry, algebra, and so on, plus Latin and Greek." ${ }_{3}$

The 1849 Catalogue of Clarenceville Academy, along the border of Clarenceville, Canada East (as Lower Canada was renamed in 1841) and St. Alban's, Vermont, offers a similar picture. The directors of that academy, in fact, printed a synopsis of the course of studies in their catalogue, differentiating their main practical course offerings of 26 subjects from the only two classical course offerings of Latin and Greek. ${ }^{34}$ Like the Charleston and Stanbridge academies, a practical curriculum dominated. Unlike those academies, Clarenceville differentiated itself by offering courses in Political Economy and Principles of Government. As will be discussed in more detail below, these courses were taught with American textbooks. We can safely assume, then, that despite the school being located in Canada East, the basis of these two courses were not British or Colonial politics, but rather American politics. Teachers at Clarenceville Academy, in other words, were transmitting American political knowledge, and its associated tenets and values, to Canadian children.

Instruction in American principles of government makes sense, however, when we consider the Eastern Townships'shared geography with New England and its similar rural demographic makeup. Like the academies of New England, the practical curriculum that we find in the Eastern Townships emanated from what American historians have described as a type of populism evoked from a Jeffersonian commitment to the nobility of life on the land. ${ }^{35}$ Unlike the urban student who was afforded the leisure and liberty to learn for its own sake, the rural student's education had to be put to good use. Seen in this light, the academies served as an equalizing force that was able to redress the growing inequalities of urban and rural education. ${ }^{36}$ Like the academies of New England, and particularly those of rural New England, the academies of the Eastern Townships offered an education to children and adolescents regardless of social class and standing, and, moreover, they offered an education that promised to be useful to the rural community and economy while preparing students for popular engagement in the political life of the colony. Yet, not all inhabitants were satisfied that a sufficient American curriculum was being offered. Marcus Child, the first School Inspector in Lower Canada's Eastern Townships, in fact, often condemned the quality of local academies and, as Little points out, "contradicted Stanstead Seminary's claim that its curriculum was 'designed to be sufficient to qualify Students to enter any of the American Colleges."'37

The popularity of the New England model of academies among residents of the Eastern Townships, and the constant threat of losing students to those academies, might have also induced academy leaders in the Eastern Townships to adopt a more rigorous American curriculum. The Stanstead Journal, as noted above, had been 
reporting for years on the "notorious fact that several schools in the neighbouring state of Vermont, receive a large portion of their patronage from these Townships." 38 Indeed, Marcus Child himself had such a low opinion of local academies that he opted to send his own daughter to a New England college for girls and his son to the High School of Montreal. ${ }^{39}$ The solution to the retention problem, according the Stanstead Journal, was to be more American. On 6 September 1849, the newspaper applauded Stanstead Seminary for its appropriation of American educational innovations. "We are informed that a new Chemical and Philosophical Apparatus has been recently procured," the newspaper read, "adding a new inducement for pupils to pursue their Academical [sic] course at this Institution. It is a well known fact, that a large number of the young people of the Eastern Townships, have annually visited the neighboring State of Vermont, for the purpose of preparing themselves to teach Common Schools, or to pursue a Classical course. Whatever may have been the inducements to go away to school heretofore, we cannot learn that there are any now." ${ }^{40}$ Proximity to the United States, then, not only allowed for the southnorth travel of educational ideas, but also for the north-south movement of students into the American academies. According to the Stanstead Journal, however, adopting American innovations would eliminate "the inducements usually urged in recommending Vermont Schools." ${ }^{41}$

\section{The Influx and Influence of American Books}

American influences in the curriculum can be more concretely seen and better understood by examining the books used in the academies of the Eastern Townships. Surviving lists of books used in the academies kept in local archives combined with lists printed in the various Reports of the Superintendent of Education for Lower Canada suggest that the majority of books used in the academies originated in the United States. These American books helped shaped the thinking and learning of the students. To be sure, this is not a new theme in Canadian educational history. Accounts of schooling in Canada West before 1846, by both school reformers at the time and, later, historians of education, have accepted the view that while American books were widely used in the colony's schools, there was also considerable resistance to them. ${ }^{42}$ Emanating from the foreign republic, American books were considered dangerous tools of republican indoctrination. While at first American books were often relied upon due to a scarcity of printed school material in British North America, by mid-nineteenth century, the historiography demonstrates, their use waned and school advocates were adamant about the inappropriateness and downright danger of republican ideas being spread through American books.

If that was the case in the rest of English Canada, however, it does not seem to have been so in the Eastern Townships. ${ }^{43}$ While school inspector Marcus Child complained to Meilleur about the use of American school books, he did not "condemn the use of these books," and their use in the Eastern Townships proliferated. ${ }^{44}$ American books dominated the catalogue of Clarenceville Academy, for example, including the use of American educational reformer William Harvey Wells' book 
on English grammar, and a book by Columbia University's legal scholar James Kent that was used to teach the "Principles of Government" course. At a time when Upper Canadian school advocates were appalled by the use of American books, the academies of the Eastern Townships were openly advertising their use, and, considering their curriculum, we might be right to even question the extent to which we can say that a "Canadian" education was offered. ${ }^{45}$

Books used at Charleston Academy also highlight the extent to which American influence was present in the Eastern Townships academies. A surviving list of books for 1847 indicate that the majority of books used were written and published in the United States. Among them, English was taught with the American Rhetorical Reader, compiled by Ebenezer Porter, the son of Vermont politician and judge Thomas Porter. Geography was taught using Jesse Olney's School Geography, widely touted to have revolutionized the teaching of Geography in the United States. The textbooks of New York mathematician and teacher Charles Davies were used to teach Algebra, Geometry and Surveying. The American surgeon and writer John Lee Comstock's schoolbooks were used to teach Natural Philosophy and Chemistry. Even in the classics, American books were favoured. Latin Grammar, for example, was taught through Ethan Allen Andrews and Solomon Stoddard's Latin Exercises. ${ }^{46}$ The prospectus of Stanbridge Academy, published in 1860, paints the same picture. The American Salem Town's Readers and Speller and Definer were used to teach English; Webster's was also the preferred dictionary in the academy. Geography was taught with the use of books by New Englanders Sarah S. Cornell and Samuel Augustus Mitchell. Boston's Warren Colburn's First Lessons in Intellectual Arithmetic was used to teach Math, and, as with Clarenceville Academy, Davies' textbooks were used to teach Algebra. ${ }^{47}$

In fact, evidence of the use of American books in the Eastern Townships extends beyond the catalogues of the various academies. In a study of the holdings of Eastern Townships libraries in the nineteenth century, Pierre Rastoul finds that the vast majority of books, including schoolbooks, were purchased in the United States. Not only did the people of the Eastern Townships emulate the popular "social libraries" conceptualized by Benjamin Franklin in the eighteenth century and commonly found throughout New England in the nineteenth century, but they also shared travelling libraries and participated in the exchange of books with their American neighbours along the border. ${ }^{48}$ This is hardly an indication of a fear of American ideas and influences penetrating the minds of Canadian children and adolescents via American books. What we see in the academies and the educational culture of the Eastern Townships resembles not anxiety about American values, but rather something closer to a cultural synthesis of the two countries. Understanding this synthesis could help us better understand the extent to which American ideas penetrated into Canada and impacted what children learned in the Eastern Townships and beyond.

\section{The Influence of American Teachers}

American teachers were also a defining feature of the Eastern Townships academies. As is the case with books, Canadian educational historiography is littered with accounts 
of the fear of American teachers. As historians of Upper Canada have noted, complaints about the negative influence of American teachers were common in the colony. ${ }^{49}$ Similar complaints are not as common in Lower Canada, and virtually nonexistent in the Eastern Townships. In fact, the Eastern Townships relied upon a steady stream of American teachers in order to support education in the region. Since there were no normal schools in Lower Canada prior to 1856, J.I. Little points out, "most of the better-educated teachers in the Eastern Townships had attended academies or colleges, either locally or in Vermont." 50

In her study of Quebec English Protestant education in the nineteenth century, Anne Drummond notes that of the almost four hundred different academy teachers she identifies in the Eastern Townships between 1829 and 1862, the majority were American. ${ }^{51}$ The most important supply of teachers and schoolmasters for the Eastern Townships academies was the University of Vermont and, to a lesser extent, Dartmouth College in New Hampshire. In an era with no teaching certificates, it was up to boards of trustees to decide if an applicant met their standards. Tellingly, it was usually the American applicants who were deemed most fit to teach — although such a statement should be made with caution. The majority of American teachers can perhaps also attributed to the sheer number of applicants with American backgrounds. Records of applications to Charleston Academy housed at the Stanstead Historical Society Archives demonstrate that of the forty-one surviving records of teachers who applied to teach at the Charleston Academy from 1837 to 1863, twenty-three were American, and many of the Lower Canadians were trained in the United States themselves. ${ }^{52}$

Identifying the precise number of American teachers employed in the Academies is difficult given the available archival record. Other sources are helpful, however, and often point to the prevalence of American teachers. The Stanstead Journal, for example, regularly reported on public examinations, including the names and origins of teachers, such as John A. James, of Irasburg, Vermont. ${ }^{53}$ Advertisements for local academies would often provide the credentials of its teachers. So, for example, while we do not know the birth origins of James B. Howard, a teacher at Barnston Academy in 1851, we do know that he was "a graduate of one of the most distinguished New England Colleges, who will teach thoroughly all the branches usually taught in similar institutions in New England." ${ }^{54}$ Henry Hubbard was a pupil and assistant teacher at Stanstead Seminary before continuing his studies at St. Johnsbury Academy and the University of Vermont. He became principal of Croftsbury Academy in Vermont, before returning to Lower Canada in 1856 in order to take the helm at Barnston Academy and, then in 1858, Danville Academy, where he remained for one year before being appointed inspector of schools for the District of St. Francis. ${ }^{55}$ It was not uncommon for the Stanstead Journal, in its "Forest and Clearings Update," a section devoted to keeping the small community a close-knit one, to report on the pupils of the various academies. These reports give us additional insight into the American origins and training of academy teachers in the Eastern Townships. We know that Ms. Gale of Stanstead Academy, for example, advanced her education in Vermont and returned to teach in the schools and academies of the Eastern Townships. ${ }^{56}$ And while his name was not provided, in another article reflecting on the Charleston Academy's 
catalogue of 1847, the Stanstead Journal attributed the academy's growing attendance numbers to the popularity of its new American principal. ${ }^{57}$

One significant American teacher who influenced education in the Eastern Townships was Alexander Twilight. Though little has been written about him in either Canadian or American educational historiography, his biography in many ways embodies the very essence of American influences on education in the Eastern Townships. It also helps us better understand the ease with which inhabitants of the Eastern Townships and New England traversed the border, and gives meaning to the ways in which the people of this borderland lived their lives as a shared experience within a single community.

Twilight was born in Corinth, Vermont on 23 September 1795, the third of six children in a mixed race family. He was the first African-American person known to have earned a degree in the United States, at Middlebury College in 1823. He spent most of his early adult life teaching in various schools and academies throughout Vermont, New Hampshire, and New York State. He also studied for the ministry with the Congregational Church and served as a minister in many of the communities where he took up teaching positions. In 1847, he moved to Shipton, Canada East (now Richmond, Quebec) where he taught and preached. At Shipton he established a small private school, referred to by locals as "Twilight's Academy." 58 He later moved to Hatley, Canada East, where he took a position at Charleston Academy. Twilight left the Eastern Townships in 1851 and returned to his home state of Vermont, where he continued to teach along the Canadian border in Orleans, and serve as a minister, until his death in 1857.59 The presence of an African-American, and Congregationalist minister, teaching the children of a British colony in the Eastern Townships ought to help us better imagine the complex ways in which Canadians and Americans in this region shared a common educational experience and a common history. Considering that their neighbours in other parts of English Canada, notably Upper Canada, were struggling with the concept and creation of separate schools (both by race and religion) during this time, it is striking that the children of the Eastern Townships, like their American neighbours in Vermont, were being taught by the very people those Upper Canadian schools were separating from the mainstream schools.

While the extent to which racial origins were or were not a matter of contention in the academies and schools of the Eastern Townships requires further research, what is clear is that a teacher's national origin seems to have mattered little in the Eastern Townships of Lower Canada. American teachers moved across the border with ease, bringing with them the cultural practices, innovations, and meanings of American education. Considering it separately, a few hundred American teachers might seem to have had a moderate impact; but viewed together with the influence of American books, curriculum, and the academy's organizational structure, and that American influence becomes substantial. To further contextualize this influence, we can also consider the extent to which the Eastern Townships was a borderland world in which school children crossed regularly between Lower Canada and Vermont along what was essentially a disregarded border. In the records of Clarenceville Academy, for example, we find not only the presence of American teachers, but of American students 
themselves. Of the 41 boys listed in 1849, eight resided on the American side of the border in Vermont; of the twenty-one girls, three were Vermonters. ${ }^{60}$ And this is not an isolated case. Americans and Canadians crossing the border to attend each other's schools was a common phenomena. It was a practice that continued throughout the nineteenth century and well into the twentieth. ${ }^{61}$ These children who traveled back and forth across the border daily, and the parents who sent them, knew what every researcher and resident of borderlands comes to know. Namely, that the closer one gets to the border, the less visible it becomes.

\section{Conclusion}

The emergence of academies demonstrates that, for much of the nineteenth century, education in the Eastern Townships was much more American than it was Canadian. By 1875 , this began to change, with influence increasingly coming from Quebec City and educational plans becoming much more centralized. Two major historical developments resulted in this shift. The first was the consolidation of the provincial Department of Public Instruction in the 1860s and 1870s, and increased centralized control and administration of schooling within the province. The second was the influx of French-Canadian settlers into the Eastern Townships in the mid- to late nineteenth century, generating a demographic turn that resulted in a decline of Anglo-American influence on public policy in the region. The academies of the Eastern Townships, predominantly based on the New England model, were eventually appropriated by the province and integrated into the provincial school system; but their early influence and impact on schooling in the formative years was pivotal for the region and beyond.

The history of the academies also challenges us to rethink the historiography of education in Canada. While histories of education in Canada have repeatedly pointed to anti-Americanism as a contributing factor to the formation of public schooling, we know, as historian Amy von Heyking has suggested, that shared social, political, and economic trends shaped a common experience in the making of public schooling in both nations. ${ }^{62}$ Yet, we understand surprisingly little about that shared experience, especially in the early years, and have instead held on to an anti-American narrative of school formation in the nineteenth century. The Eastern Townships stands as an example in which the narrative of anti-Americanism in the nineteenth century is directly challenged. American influence may have in fact been a major contributor to the development of schooling in the region and shaped part of the direction of schooling in the province as a whole. American settlers in the Eastern Townships were part of a borderland world that helped shape their educational ideas. When we consider this, what emerges is a unique perspective that helps us better understand Quebec educational history in a cultural context that is less static, monolithic, and detached from the rest of the world than it has been previously characterized. The Eastern Townships demonstrates that the educational experiences of certain Canadians above the forty-ninth parallel were influenced by the culture, people, and intersection of communities along an invisible border. 


\section{Notes}

1 Anzaldúa, Gloria, Borderlands/La Frontera: The New Mestiza (San Francisco: Aunt Lute, 1987); Renato Resaldo, Culture and Truth: The Remaking of Social Analysis (Beacon Press, 1993); Emily D. Hicks, Border writing: The Multidimensional Text (Minnesota: Univeristy of Minnesota Press, 1991); Héctor Calderón José David Saldívar, Criticism in the Borderlands: Studies in Chicano Literature, Culture, and Ideology (Chapel Hill, NC: Duke University Press, 1991).

2 See Oscar J. Martinez, Border People: Life and Society in the U.S.-Mexico Borderlands (Tucson: University of Arizona Press, 1994); Josiah Heyman, Life and Labor on the Border: Working People of Northeastern Sonora, Mexico, 1886-1986 (Tucson: University of Arizona Press, 1991); David Spencer and Kathleen A. Staudt (eds.), The U.S.-Mexico Border: Transcending Divisions, Contesting Identities (Boulder: Lynne Rienner Publishers, 1998); Pablo Vila, Crossing Borders, Reinforcing Borders: Social Categories, Metaphors, and Narrative Identities on the U.S.-Mexico Frontier (Austin: University of Texas Press, 2000); Joseph Nevins, Operation Gatekeeper: The Rise of the 'Illegal Alien' and the Making of the U.S.-Mexico Boundary (New York: Routeledge, 2002); Pablo Vila, Border Identifications: Narratives of Religion, Gender, and Class on the U.S.-Mexico Border (Austin: University of Texas Press, 2005).

3 See W.H. New, Borderlands: How We Talk about Canada (Vancouver: University of British Columbia Press, 1998); James Laxer, The Border: Canada, the U.S., and Dispatches from the $49^{\text {th }}$ Parallel (Toronto: Anchor Canada, 2003).

4 Two notable exceptions are Amy von Heyking's essay, "Ties that Bind? American Influences on Canadian Education," Education Canada 44, 4 (2004): 30-34, and Kerry Alcorn's recent study on American educational influences in early twentieth century Saskatchewan, Border Crossings: U.S. Culture and Education in Saskatchewan, 19051937 (Montreal and Kingston: McGill-Queen's University Press, 2013).

5 See especially Louis-Philippe Audet's seminal study, Le système scolaire de la province de Québec, 6 volumes (Quebec: Éditions de l'Érable, 1950-1956); John Adams, The Protestant School System in the Province of Quebec (Montreal: E.M. Renouf, 1902); W.P. Percival, Life in School: An Explanation of the Protestant School System of the Province of Quebec (Montreal: Herald Press, 1940); W.P. Percival, Across the Years: A Century of Education in the Province of Quebec (Montreal: Gazette Publishing Co. Ltd, 1946); K.J. Dowd, "The First County Central School Board in Quebec." MA, McGill University, 1956; C.E. Phillips, The Development of Education in Canada (Toronto: Gage, 1957).

6 Louis-Philippe Audet, Histoire du Conseil de l'instruction publique de la province de Québec 1856-1964. (Montréal: Éditions Leméac, 1964); Louis-Philippe Audet and Armand Gauthier. Le Système scolaire du Québec, organisation et fonctionnement (Montréal: Éditions Beauchemin Ltée, 1967); J. Donald Wilson, Robert M. Stamp, Lous-Philippe Audet (eds.), Canadian Education: A History (Toronto: Prentice-Hall, 1970); Louis-Philippe Audet, Histoire de l'enseignement au Québec, 1608-1971, 2 vols. (Montreal: Holt, Rinehart, and Winston, 1971).

7 See especially Andrée Dufour, Tous à l'école: État, communautés rurales et scolarisation au Québec de 1826 à 1859. (Ville La Salle: Éditions Hurtubise HMH, 1996); J.I. Little, State and Society in Transition: The Politics of Institutional Reform in the Eastern Townships, 1838-1852 (Montreal and Kingston: McGill-Queen's University Press, 1997); Thérèse Hamel, Jacques Tondreau et Michel Morisset. De la terre à l'école : histoire de l'enseignement agricole au Québec, 1926-1969 (Montréal, Hurtubise HMH, 2000); Roderick MacLeod and Mary Anne Poutanen, A Meeting of the People. School Boards and Protestant Communities in Quebec, 1801-1998 (Montreal and Kingston: McGill-Queen's University Press, 2004); Roger Magnuson, The Two Worlds of Quebec Education during the Traditional Era, 1760-1940 (London, ON: Althouse Press, 2005); Bruce Curtis, Ruling By Schooling Quebec: Conquest to Liberal Governmentality: A Historical Sociology (Toronto: University of Toronto Press, 2012). 
8 Curtis, Ruling By Schooling Quebec, 7.

9 J.I. Little, State and Society in Transition, 171-201; J.I. Little, "School Reform and Community Control in the 1840s: A Case Study from the Eastern Townships," Historical Studies in Education/Revue d'histoire de l'éducation 9 (1997): 153-164; J.I. Little, "'Labouring in a Great Cause:' Marcus Child as Pioneer School Inspector in Lower Canada's Eastern Townships, 1852-59," Historical Studies in Education/Revue d'histoire de l'éducation 10 (1998): 85-115.

10 Anne Drummond, "From Autonomous Academy to Public 'High School': Quebec English Protestant Education, 1829-1889.” (MA, McGill University, 1986); Anne Drummond, "Gender, Profession, and Principals: The Teachers of Quebec Protestant Academies, 1875-1900." Historical Studies in Education/Revue d'histoire de l'éducation 2, 1 (1990): 59-71 Historical Studies in Education/Revue d'histoire de l'éducation 2, 1 (1990): 59-71; Anne Drummond, “'New Educationists' in Quebec Protestant Model and Intermediate Schools, 1881-1926.” (PhD, University of Ottawa, 1994).

11 Kerry Alcorn, Border Crossings: U.S. Culture and Education in Saskatchewan, 1905-1937 (Montreal and Kingston: McGill-Queen's University Press, 2013).

12 Ibid., 94-97.

13 William Doyle, The Vermont Political Tradition: And Those Who Helped Make It (Montpelier, Vermont: Leahy Press, 1984, r. 2009), 63-79.

14 Theodore R. Sizer, The Age of the Academies (New York: Teachers College, 1964), 6; Kathleen H. Brown, Schooling in the Clearings: Stanstead, 1800-1850 (Stanstead: Stanstead Historical Society, 2001), 137.

15 Theodore R. Sizer, The Age of the Academies, 6.

16 Kathleen H. Brown, Schooling in the Clearings, 138.

17 Unlike, by way of example, their counterparts in Upper Canada.

18 "An Act for the Establishment of Free Schools and the Advancement of Learning in the Province." The Provincial Statues of Lower Canada, 2-3: 128.

19 Roger Magnuson, The Two Worlds of Quebec Education, 18.

20 Bruce Curtis, Ruling By Schooling Quebec, 86.

21 Henry Leslie Rennie, History of Education in the Eastern Townships (MA, Bishop's University, 1930), 33.

22 Anne Drummond, "From Autonomous Academy to Public 'High School,' 17.

23 Henry Leslie Rennie, History of Education in the Eastern Townships, 33-34.

24 J.I. Litte, State and Society in Transition, 171.

25 Kathleen H. Brown, Schooling in the Clearings, 139.

26 Legislative Assembly of the Province of Canada. Report of the Superintendent of Education for Lower Canada, For the Scholastic Year 1846-7 (Montreal: Lovell and Gibson, 1848), 23-24.

27 Stanstead Seminary was established in 1829 in Stanstead, Quebec. Despite its name, it had no religious affiliation and was an academy for all intents and purposes.

28 Stanstead Journal 16 November 1848.

29 Kathleen H. Brown, Schooling in the Clearings, 150.

30 Stanstead Historical Society (STHS), Charleston Academy Files, F1T2, File 1 of 27.

31 Legislative Assembly of the Province of Canada. Report of the Superintendent of Education for Lower Canada, For the Scholastic Year 1856-7 (Toronto: John Lovell, 1857).

32 Prospectus of Stanbridge Academy" (1860), in Rennie, History of Education in the Eastern Townships, 54-55.

33 J.I. Little, State and Society in Transition, 227.

34 Catalogue of Clarenceville Academy, Canada East, 1849 (Burlington, Vermont: C. Goodbrich, 1849), 37-38.

35 Jackson Lears, Rebirth of a Nation: The Making of Modern America, 1877-1920 (New York: Harper Perennial, 2010), 158; Kerry Alcorn, Border Crossings, 94. 
36 Charles Postel, The Populist Vision (New York: Oxford University Press, 2009), 46-49; Alcorn, Border Crossings, 94-95.

37 J.I. Little, "Labouring in a Great Cause," 99.

38 Stanstead Journal, 25 February 1847.

39 J.I. Little, “'Labouring in a Great Cause," 99.

40 Stanstead Journal, 6 September 1849.

41 Ibid.

42 Bruce Curtis, "Schoolbooks and the Myth of Curricular Republicanism: The State and the Curriculum in Canada West, 1820-1850," Histoire sociale/Social History 16, 32 (1983): 305-329; Susan E. Houston and Alison L. Prentice, Schooling and Scholars in Nineteenth-Century Ontario (Toronto: University of Toronto Press, 1988).

43 In fact, recent scholarship by Scott McLaren suggests that historical accounts of "the problem of American books in Upper Canada," may themselves be exaggerated. See Scott McLaren. "Anti-British in Every Sense of the Word? Methodist Preachers, School Libraries, and the Problem of American Books in Upper Canada, 1820-1860." Historical Papers: Canadian Society of Church History (2013): 57-78.

44 J.I. Little, "Labouring in a Great Cause," 104.

45 It is also interesting to note, I think, that Clarenceville Academy's catalogue was itself printed in Burlington, Vermont, as were many of the academy and school catalogues in nineteenth-century Eastern Townships.

46 STHS, Charleston Academy Files, F1T2, File 1 of 27.

47 "Prospectus of Stanbridge Academy" (1860), in Rennie, History of Education in the Eastern Townships, 54-55.

48 Pierre Rastoul, "Nineteenth Century Libraries in Stanstead," Stanstead Historical Society Journal, 24 (2011): 107-117.

49 J. Donald Wilson, "The Teacher in Early Ontario," in Frederick H. Armstrong, J. Donald Wilson, Aspects of Nineteenth Century Ontario: Essays Presented to James J. Talman (Toronto: University of Toronto Press, 1974, 218-236); Bruce Curtis, "Schoolbooks and the Myth of Curricular Republicanism: The State and the Curriculum in Canada West, 1820-1850," Histoire sociale/Social History 16, 32 (1983): 305-329; R.D. Gidney and W.P.J. Millar, Inventing Secondary Education: The Rise of the High School in Nineteenth-Century Ontario (Montreal and Kingston: McGill-Queen's University Press, 1990); Harry Smaller, "Teachers and Schools in Early Ontario," Ontario History 85, 4 (1993): 291-307; Elaine Gold, "Teachers, Texts and Early Canadian English 1791-1841," Proceedings of the 2003 Annual Conference of the Canadian Linguistic Association (Montreal: Universite du Quebec a Montreal, 2004), 85-96.

50 J.I. Little, “'Labouring in a Great Cause,"” 99.

51 Anne Drummond, "From Autonomous Academy to Public 'High School," 21.

52 STHS, Charleston Academy Files, F1T2, File 10 "Correspondence-Teaching Positions, 1837-1849," and F1T2, File 11 "Correspondence-Teaching Positions, 1854-1863."

53 Stanstead Journal, 19 November 1846

54 Stanstead Journal, 14 August 1851.

55 B.F. Hubbard, The History of Stanstead County, Province of Quebec, with Sketches of More than Five Hundred Families, n.p., 1874.

56 Stanstead Journal, 6 July 1844.

57 Stanstead Journal, 25 February 1847.

58 Henry Leslie Rennie, History of Education in the Eastern Townships, 56.

59 Orleans County Historical Society (OCHS), Old Stone House Museum, Biographies, "Alexander Twilight."

60 Catalogue of Clarenceville Academy, Canada East, 1849, 34-36. 
94 Historical Studies in Education/Revue d'histoire de l'éducation

61 See Anthony Di Mascio, "Cross-Border Schooling and the Complexity of Local Identities in the Quebec-Vermont Borderland Region: A Historical Analysis." Journal of Eastern Township Studies / Revue d'études des Cantons-de-l'Est 41, 2 (2013): 37-54.

62 Amy von Heyking, "Ties that Bind? American Influences on Canadian Education," Education Canada 44, 4 (2004): 30-34. 